\title{
КЛІНІЧНИЙ FUZZY - КОНТРОЛЕР В ОЦІНЦІ НЕЛІНІЙНИХ ОСОБЛИВОСТЕЙ ВАРІАБЕЛЬНОСТІ СЕРЦЕВОГО РИТМУ І ЛІКУВАННІ ГІПЕРТЕНЗИВНИХ УСКЛАДНЕНЬ ВАГІТНОСТІ
}

\author{
В. А. Сидоренко, В. П. Куценко, Д. В. Вакуленко, А. С. Сверстюк, І. Є. Андрущак \\ Донецький національний технічний університет \\ Інститут інформатики і штучного інтелекту
}

Тернопільський державний медичний університет імені І. Я. Горбачевського

\begin{abstract}
У роботі досліджується вибір параметрів функціонального статусу організму вагітних, можливість та цінність його динамічної діагностики. Дослідження проводяться на базі вивчення показників варіабельності серцевого ритму (BCP) матері, які дозволяють отримати актуальну оцінку стану вегетативної нервової системи (ВНС) організму і контроль ефективності терапії за допомогою алгоритмів нечіткої логіки. Формалізація вибору змінних для контролю введення медикаментів, враховуючи системні реакції ВНС при ускладненнях вагітності, $є$ недостатньо вивченою, але в той же час має великі резерви для зниження показників захворюваності і смертності.
\end{abstract}

Ключові слова: варіабельність ритму серця, інфузомат, клінічна система управління, клінічний контролер нечіткої логіки, Fuzzy-controller, PID-controller, $a_{1}$, вагітність.

\section{КЛИНИЧЕСКИЙ FUZZY - КОНТРОЛЛЕР В ОЦЕНКЕ НЕЛИНЕЙНЫХ ОСОБЕННОСТЕЙ ВАРИАБЕЛЬНОСТИ СЕРДЕЧНОГО РИТМА И ЛЕЧЕНИИ ГИПЕРТЕНЗИВНЫХ ОСЛОЖНЕНИЙ БЕРЕМЕННОСТИ}

\author{
В. А. Сидоренко, В. П. Куценко, Д. В. Вакуленко, А. С. Сверстюк, И. Е. Андрущак \\ Донецький национальний технический университет
}

Институт информатики и искусственного интеллекта

Тернопольський государственный медицинский университет им. И. Я. Горбачевского

В работе рассматривается выбор параметров функционального статуса организма беременных, возможность и ценность динамической диагностики тяжести преэклампсии, на базе изучения показателей вариабельности ритма сердца матери, позволяющих получить текущую оценку состояния вегетативной нервной системы (ВНС) организма беременных, расчет дозировок медикаментов и контроль эффективности проводимой терапии посредством алгоритмов нечеткой логики. Формализация набора входных переменных для управляющих введением медикаментов устройств с учетом системных реакций ВНС в патогенезе осложнений беременности остается недостаточно изученной, хотя здесь имеются большие резервы для снижения показателей материнской и перинатальной заболеваемости и смертности.

Ключевые слова: вариабельность ритма сердца, инфузомат, клиническая система управления, клинический контроллер нечеткой логики, Fuzzy-controller, PID-controller, $a_{1}$, беременность.

\section{CLINICAL FUZZY CONTROLLER IN ESTIMATION OF NONLINEAR FEATURES OF HEART RATE VARIABILITY AND TREATMENT OF HYPERTENSION COMPLICATIONS OF PREGNANCY}

\author{
V. A. Sydorenko, V. P. Kutsenko, D. V. Vakulenko, A. S. Sverstyuk, I. Ye. Andrushchak \\ Donetsk National Technical University \\ Institute of Informatics and Artificial Intelligence \\ Ternopil State Medical University by I.Ya. Horbachevsky
}

\begin{abstract}
The choice of parameters of functional status of organism of the pregnant, possibility and value of dynamic diagnostics of weight of preeclampsia, are studied, on the base of study of indices of variability rhythm of heart of mother, allowing to get the current estimation of the state of the vegetative nervous system (VNS) of organism of the pregnant, calculation of dosages
\end{abstract}

() В. А. Сидоренко, В. П. Куценко, Д. В. Вакуленко та ін. 
of medicines and control of efficiency of the conducted therapy by means of algorithms of fuzzy logic. Formalization of set of entrance variables medicines introduction, taking into account the system reachions of VNS during pregnancy complications is not studied enough.

Key words: variability rhythm of heart, metering device, clinical control system, clinical conptroller of fuzzy logic, Fuzzycontroller, PID-controller, $a 1$, pregnancy.

Вступ. За наявними даними клініко -інструментальних досліджень при вагітності, ускладненій прееклампсією (ПЕ) різного ступеня тяжкості, в післяпологовому періоді спостерігається значне збільшення середнього артеріального тиску (САТ), збільшення частоти серцевих скорочень, зменшення активності барорецепції і регрес «хаотичних» властивостей варіабельності кардіоритму, порівняно з нормальним перебігом вагітності тієї ж вікової групи [1]. Неадекватна гіпотензивна терапія і неефективний контроль лікування, що проводиться, призводить до тривалих термінів реабілітації жінок з ПЕ різного ступеня тяжкості.

Існуючі системи діагностики і лікування захворювань серцево-судинної системи здійснюють реєстрацію і аналіз біологічних сигналів без врахування нелінійних (перехідних, хаотичних процесів) кардіоритмів, не надаючи при цьому варіантів аутокорекції дозування ліків, що і $є$ основним їх недоліком.

Мета дослідження. У даній роботі вивчаються показники варіабельності серцевого ритму (ВРС) $\mathrm{i}$ «хаотичні» властивості варіабельності кардіоритму (при пробах навантажень у вигляді гіпервентиляції) в групі жінок з ускладненим перебігом вагітності [2-3] 3 метою встановлення ознак, що відрізняють ускладнений перебіг вагітності і післяпологового періоду. Основним завданням дослідження було формалізувати параметри вегетативної нервової системи (BНC) у вхідні змінні в моделі PID-контролера нечіткої логіки і оптимізація клініко-діагностичного процесу, що вивчався, шляхом автоматизації визначення доз медикаментів за допомогою методів нечіткої логіки.

Матеріали і методи. За допомогою пропонованої методики обстежено 122 жінки в післяпологово- му періоді з ПЕ різного ступеня тяжкості. У II стандартному відведенні біопідсилювачем реєструвався електрокардіографічний сигнал (ЕКГ), який подавався через аналогово-цифровий перетворювач на комп'ютер. Частота сканування сигналу складала 200 Гц. Цифрові дані ЕКГ оброблялися автоматично в режимі off-line з обчисленням ряду тимчасових, частотних і нелінійних показників ВРС програмою "teleVAREOset". Початкові ряди міжсистолічних (RR) інтервалів піддавалися сплайновій інтерполяції для приведення їх до еквідистантного вигляду, аномальні RR (екстрасистоли та ін.) замінювалися усередненими інтервалами від величини $\mathrm{RR}$, віддаленого від аномального на два кардіоінтервали. Всього на кожному етапі процедури дослідження реєстрували 256 міжсистолічних інтервалів серця, які утворювали безперервний ряд у вигляді кардіотахограми. Реєстрація 300 RR тривала близько 5 хвилин [2].

В якості характеристик нелінійної динаміки і як вхідну змінну для контролера нечіткої логіки використовували показники параметра $a_{1}$ детрентного флуктуаційного аналізу (DFA). Спочатку здійснювали приведення даних до нульового середнього і будували випадкове блукання за формулою:

$y(k)=\sum_{i=1}^{n}(x(i)-\bar{x})$

де $\bar{x}$ - середнє значення часового ряду

$x(i), i=\overline{1 \ldots n}$ - часовий ряд.

На рисунках 1 і 2 наведені приклади часового ряду ЕКГ-сигналу і результату підрахунку випадкового блукання.

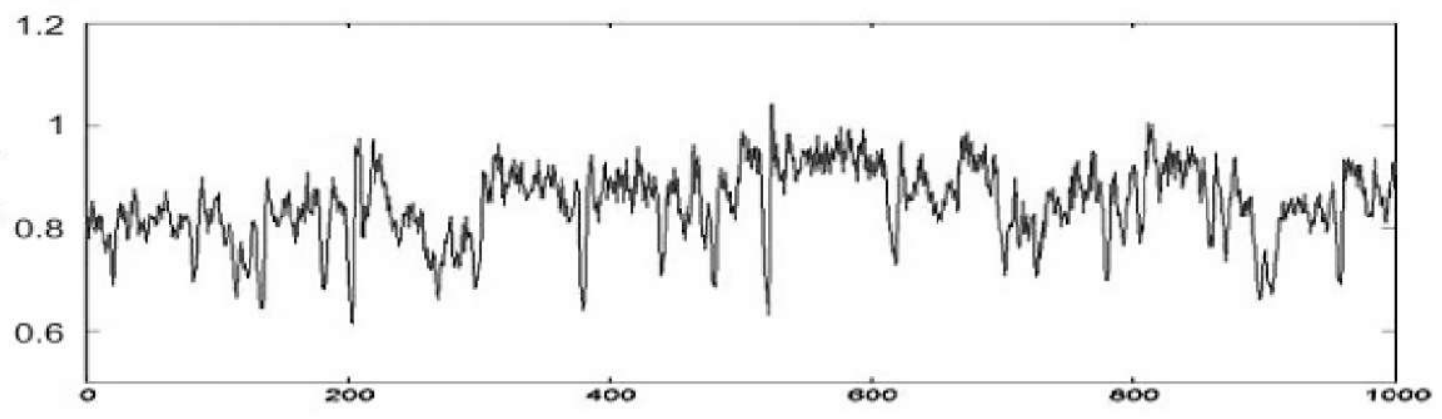

Puc. 1. Приклад часового ряду ЕКГ - сигналу. 


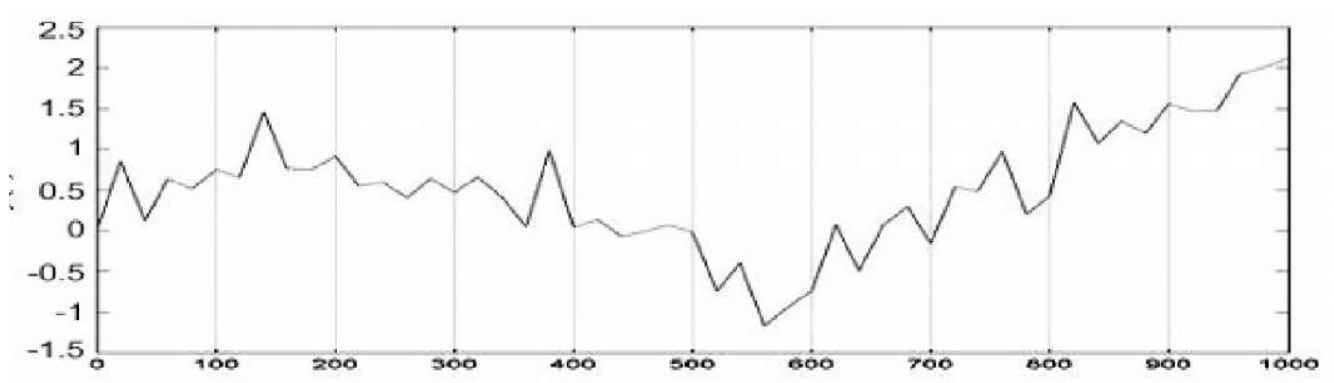

Puc. 2. Результат підрахунку випадкового блукання.

Потім ряд значень $y(k), \quad k=\overline{1 . . n}$, розбивається на відрізки довжиною $n$, що не перекриваються, в межах кожного $з$ яких методом найменших квадратів визначається рівняння прямої, що апроксимує послідовність $y(k)$.

Знайдена апроксимація $y(k)(y=k x+b)$ розглядається як локальний тренд.

Далі обчислюється середньоквадратична похибка лінійної апроксимації $F(n)$ при широкому діапазоні значень $n$ :

$F(n)=\sqrt{\frac{1}{N} * \sum_{k=1}^{N}\left(y(k)-y_{n}\right)^{2}}$,

де $y(k), 1 . . n,-$ ряд значень, отриманий на пер- $y_{n}$ - значення локального тренду.

У разі, коли залежність $F(n)$ має степеневий характер $F(n) \sim n^{\alpha}$, тобто наявність лінійної ділянки при подвійному логарифмічному масштабі $\ln F \sim \alpha \ln n$, можна говорити про існування скейлінгу. У результаті показник $a_{1}$ розраховується за формулою (3) $[5,6]$ :

$\alpha \sim \ln (F-n)$

Розрахована в результаті застосування DFA-методу змінна поступає на вхід FUZZY - контролера, що працює за принципом методу Мамдані.

На рисунку 3 наведена функція належності показника $\mathrm{a}_{1}$ для FUZZY - контролера. шому кроці,

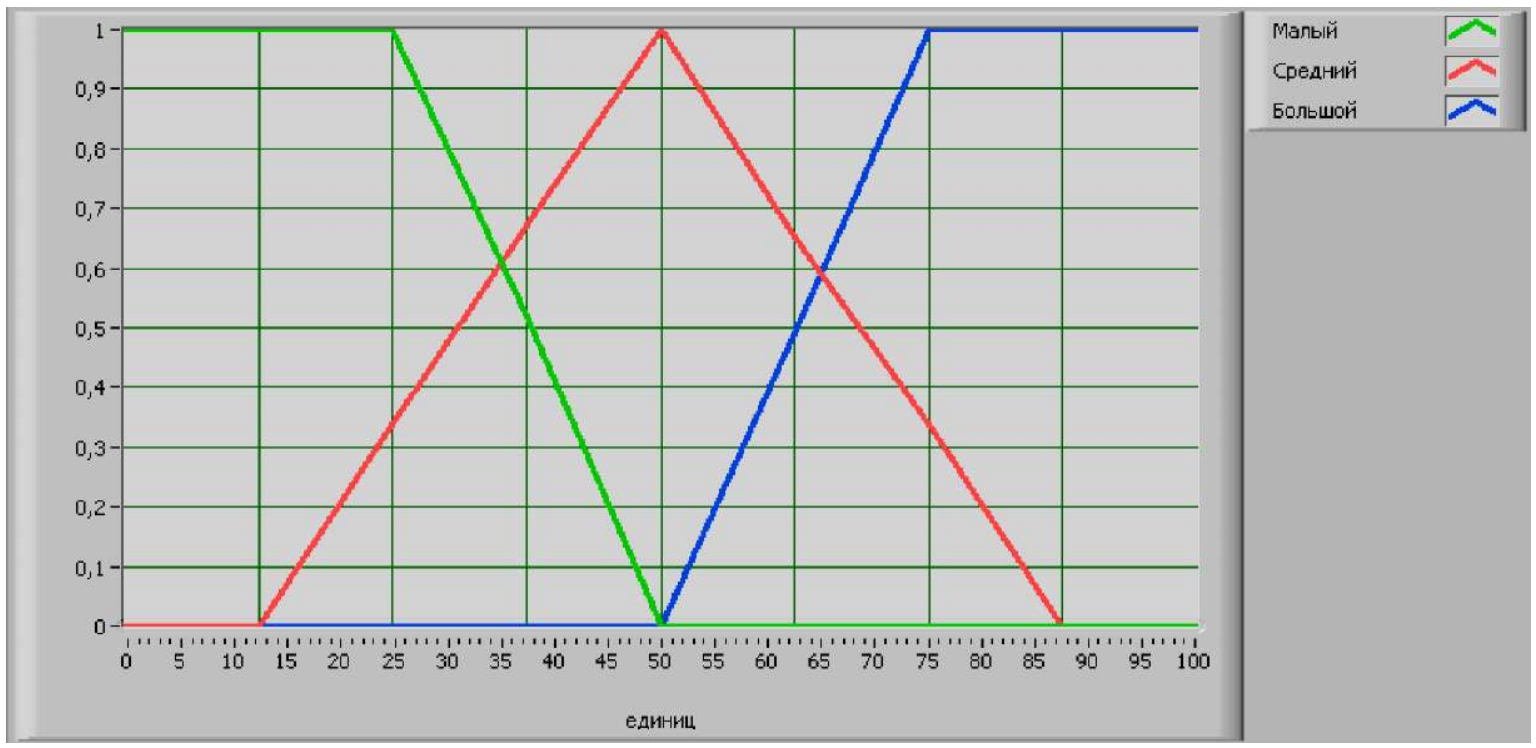

Puc. 3. Графіки функцій належності для термів лінгвістичної змінної «Показник альфа1».

Середній артеріальний тиск (САТ), як друга вхідна змінна, вимірювався за допомогою реанімаційного цифрового тонометра 3 комп'ютерним інтерфейсом. Для визначення САТ запропонована формула Хікема (4), реалізована в програмі розрахунку:
$P_{m}=\frac{A}{3}+P_{d}$

де $P_{m}$ - середній динамічний тиск,

$P_{d}$ - діастолічний тиск. 
На рисунку 4 наведена функція належності змінної «CAT».

Для корекції гемодинамічних порушень і функціональних розладів в реанімаційній практиці використовується препарат ЛАКАРДІЯ (LACARDИА, Лабеталол), блокатор альфа- і бета-адренорецепторів. ЛАКАРДІЯ - неселективний бета-адреноблокатор, який має одночасно селективну альфа-адреноблокуючу і пряму судинорозширювальну дію [7]. За рахунок альфа-блокади поєднання цих властивостей забезпечує швидку дію препарату і виражений антигіпертензивний ефект. Знижуючи артеріальний тиск цей засіб не викликає тахікардії, вводиться внутрішньовенно капельно протягом доби, максимальна кон- центрація лабеталолу спостерігається через 2 хвилини, але вже через 8,5 хвилини знижується. Період напіввиведення складає 3,5-4,5 години і не змінюється при нирковій недостатності. Виводиться з організму, головним чином, з сечею у вигляді неактивних метаболітів. Таким чином, препарат нормалізує артеріальний тиск і варіабельність серцевого ритму, його ефект добре управляється шляхом збільшення або зменшення частоти краплинної інфузії у вену хворому. Завдяки цим властивостям препарат був визначений як ефектор в клінічному циклі нечіткої логіки, що розроблявся.

На рисунку 5 наведений графік функції належності результуючої змінної дози медикамента «ДМ».

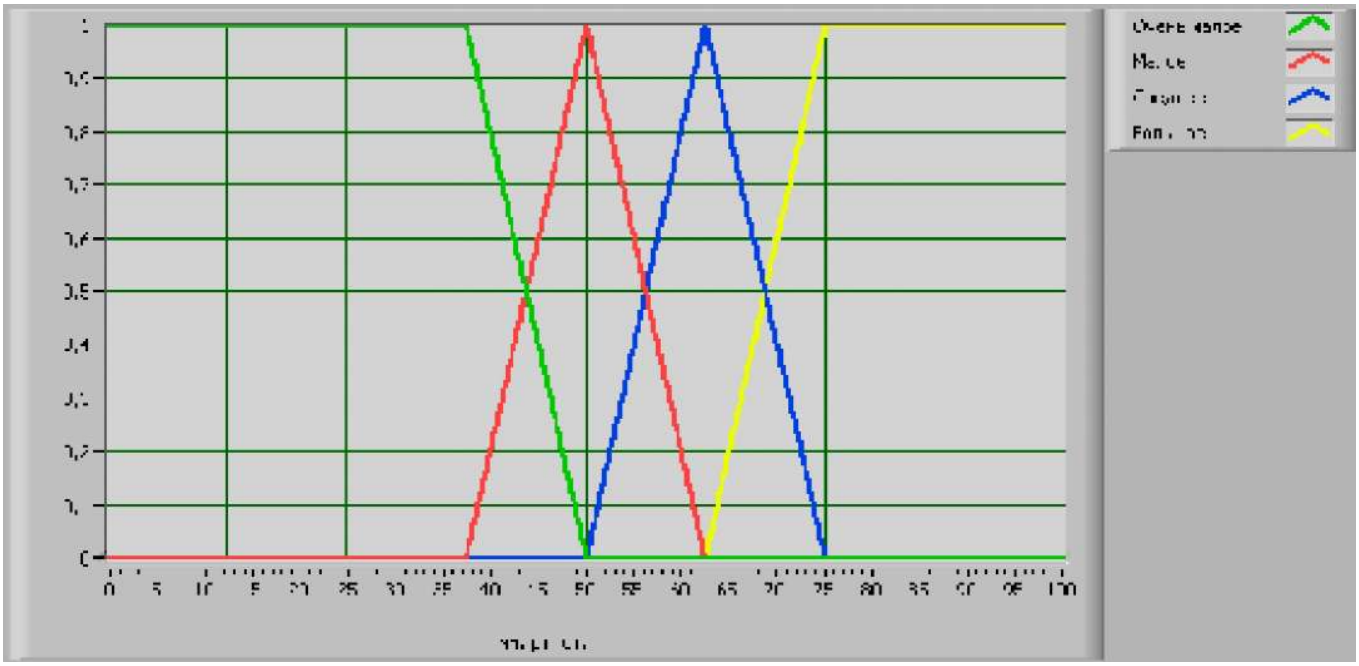

Puc. 4. Графіки функцій належності для термів лінгвістичної змінної «САТ».

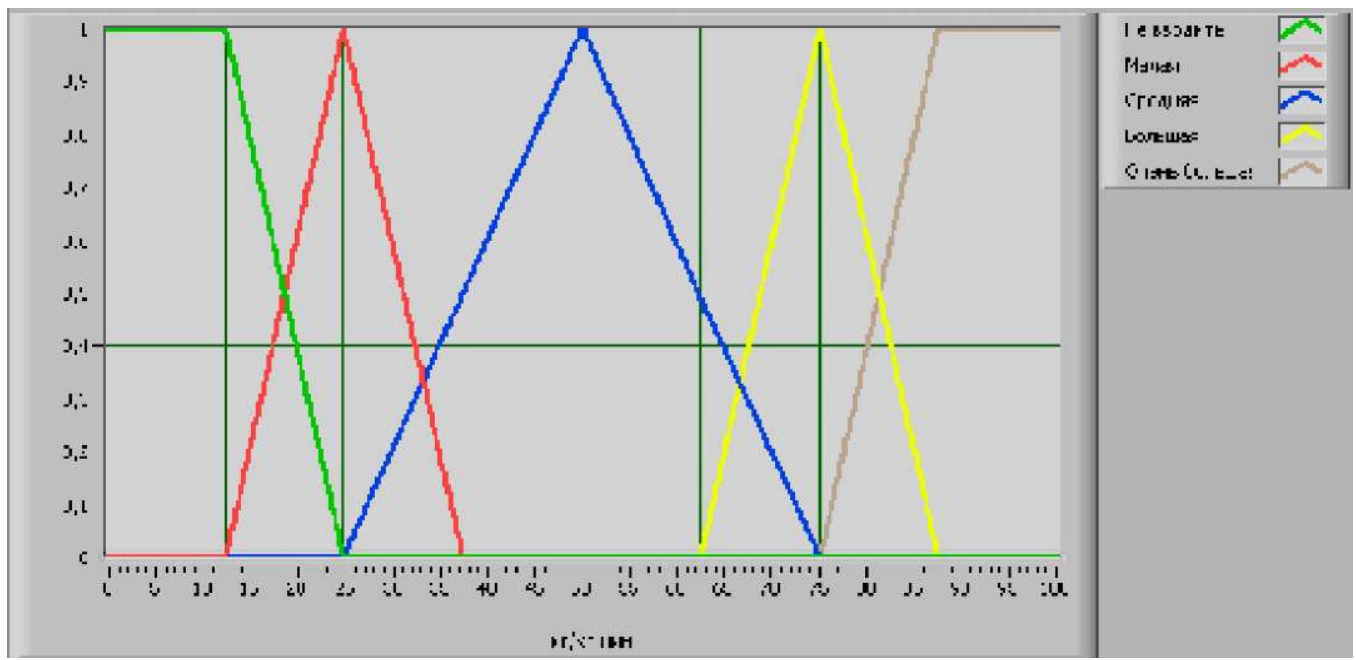

Puc. 5. Графік функції належності для термів лінгвістичної змінної «ДМ».

Була створена база з 12 нечітких правил:

1. ЯКЩО «Показник альфа1 малий» I «САТ дуже малий», ТО «ДМ не вводити»;

2. ЯКЩО «Показник альфа1 середній» I «САТ дуже малий», ТО «ДМ не вводити»;
3. ЯКЩО «Показник альфа1 великий» $\mathrm{I}$ «САТ дуже малий», ТО «ДМ мала»;

4. ЯКЩО «Показник альфа1 малий» I «СAT малий», ТО «ДМ мала»; 
5. ЯКЩО «Показник альфа 1 середній» I «САТ малий», ТО «ДМ середня»;

6. ЯКЩО «Показник альфа1 великий» I «САТ малий», ТО «ДМ середня»;

7. ЯКЩО «Показник альфа1 малий» I «САТ ceредній», ТО «ДМ мала»;

8. ЯКЩО «Показник альфа1 середній» I «САТ середній», ТО «ДМ середня»;

9. ЯКЩО «Показник альфа1 великий» I «САТ cередній», ТО «ДМ велика»;

10. ЯКЩО «Показник альфа1 малий» I «САТ великий», ТО «ДМ велика»;

11. ЯКЩО «Показник альфа1 середній» I «САТ великий», ТО «ДМ велика»;
12. ЯКЩО «Показник альфаі великий» I «САТ великий», ТО «ДМ дуже велика»;

Пропонується систему управління створити 3 наступних підсистем:

а) модуль реєстрації, підсилення і фільтрації ЕКГсигналу людини;

б) модуль АЦП і ЦАП;

в) цифровий тонометр UTAS ML300 з комп'ютерним інтерфейсом;

д) fuzzy-модуль генерації рішення і дозування медикаментів, що вводяться;

д) модуль введення медикаментів (інфузомат).

Структура системи управління наведена на рисунку 6.

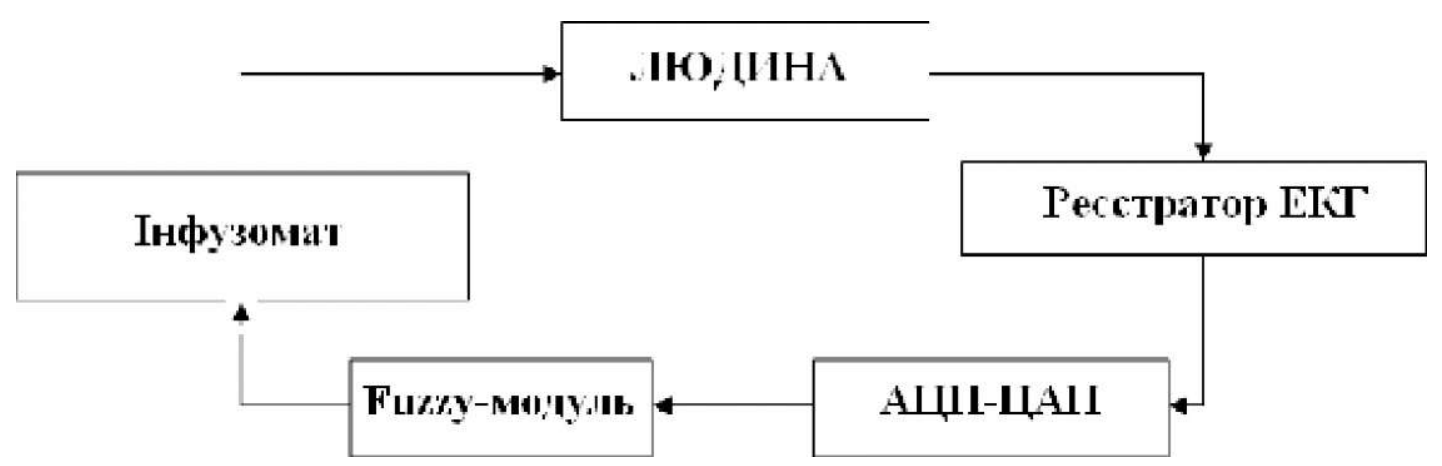

Puc. 6. Структура системи управління.

Як видно з наведеної схеми, дана структура управління $є$ замкнутою автоматизованою системою. Остаточне рішення лікаря буде необхідне при роботі блоку аналізу ЕКГ-сигналу з метою твердження або спростування запропонованих си- стемою управлінських рішень про введення медикаментів.

Результати і обговорення. У таблиці 1 наведені значення DFA коефіцієнтів при нормальній і патологічній вагітності (нелінійного аналізу ВСР).

Таблиця 1. ВСР $a_{1}$ при нормальній вагітності, гіпертензії вагітних і прееклампсії

\begin{tabular}{|l|c|}
\hline \multicolumn{1}{|c|}{ Функціональний статус } & $\alpha_{1}$ \\
\hline Норма & $0,56 \pm 0,026$ \\
\hline Гіпертензія вагітних & $* 0,59 \pm 0,12$ \\
\hline Прееклампсія легкого ступеня & $0,62 \pm 0,014$ \\
\hline Прееклампсія середнього ступеня & $0,68 \pm 0,09$ \\
\hline Прееклампсія тяжкого ступеня & $0,76 \pm 0,018$ \\
\hline
\end{tabular}

* - статистично не значуще. Результати представлені у вигляді M+SD, M - середнє арифметичне значення, SD середньоквадратичне відхилення.

Отримані результати продемонстрували статистичну достовірність у відмінності норми і патології.

Для перевірки коректності роботи система була випробувана в одній з клінічних установ міста Донецька. Лікарю пропонувалося за артеріальним тиском пацієнта визначити дозу і темп введення медикаменту.

У таблиці 2 наведені значення САТ, показника, а також дози, які визначалися лікарем і системою при обробці одних і тих же клінічних даних. У непарних рядках лікар погоджувався із запропонованою системою дозою, а в парних діяв на свій розсуд.

В результаті аналізу роботи лікаря і системи були побудовані графіки динаміки зміни САТ залежно від рішення лікаря або системи (рис. 7) і введена доза медикаменту в результаті (рис. 8).

В ході порівняльного аналізу дій і рішень лікаря в порівнянні з рекомендаціями системи виявлено: 
Таблиця 2. Результати експерименту.

\begin{tabular}{|c|c|c|c|c|}
\hline \multirow{2}{*}{} & \multicolumn{2}{|c|}{ Вхідні значення } & \multicolumn{2}{c|}{ Дозування } \\
\cline { 2 - 5 } & САТ (мм рт. ст) & $a_{1}(\mathrm{x} 100)$ & лікар (мкг/кг/хв) & система (мкг/кг/хв) \\
\hline 1 & 80 & 74 & $48^{* *}$ & $38^{* *}$ \\
\hline 2 & 76 & 72 & $42^{*}$ & $37^{*}$ \\
\hline 3 & 92 & 82 & $39^{* *}$ & $34^{* *}$ \\
\hline 4 & 88 & 62 & $37^{*}$ & $33^{*}$ \\
\hline 5 & 90 & 64 & $35^{* *}$ & $39^{*}$ \\
\hline 6 & 92 & 58 & $35^{*}$ & $29^{* *}$ \\
\hline 7 & 82 & 56 & $31^{*}$ & $28^{*}$ \\
\hline 9 & 84 & 53 & $30^{* *}$ & $27^{* *}$ \\
\hline
\end{tabular}

* - доза введена фактично, ** - розрахункова доза, взята до відома.

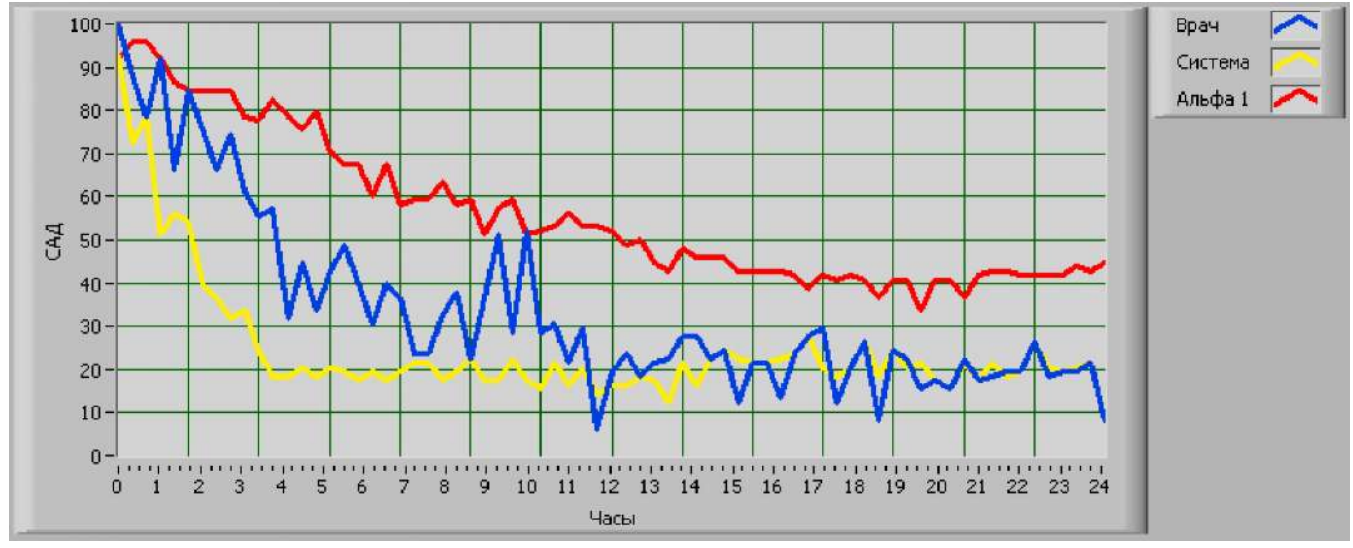

Puc. 7. Середнє значення артеріального тиску (АТ).

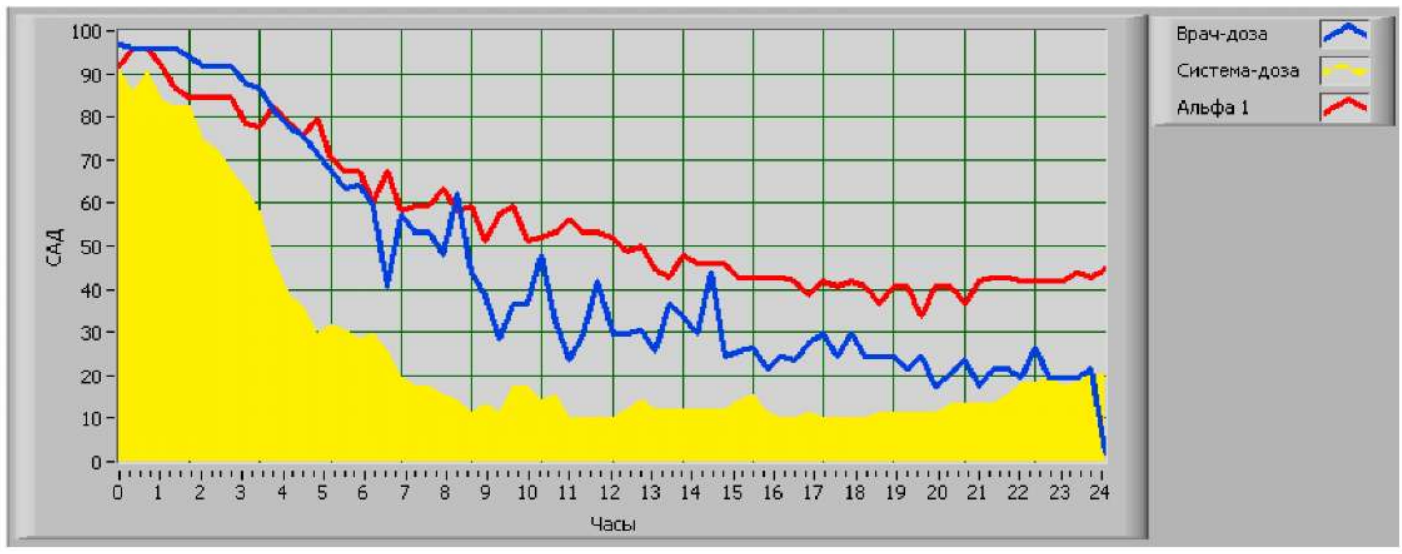

Puc. 8. Дозування медикаментів.

- в результаті неможливості частого вимірювання лікарем артеріального тиску людини і адекватної інтерпретації отриманих значень спостерігаються значні коливання АТ;

- спостерігаються періодичні значні зниження АT. Це пояснюється передозуванням медикаменту в результаті невчасного введення;

- стабілізація АТ під курацією лікаря відбувається за більш тривалий час і використовується більша кількість препарату;
- оперативно не оцінюється функціональний статус організму, прогноз на предмет можливості подальшого лікування утруднений;

Результати дії системи в порівнянні з діями лікаря:

- стабільніший графік зміни АТ;

- стабілізація АТ відбувається за коротший проміжок часу;

- менша витрата медикаментів;

- менше число прооперованих пацієнтів.

Висновки: 1. Нелінійні характеристики ВСР 
- параметр $a_{1}$ детрентного флуктуаційного аналізу (DFA, DFA) - інкапсулюють природну хаотичність ЕКГ-сигналу і уточнюють лінійні статистики ВСР.

2. Параметр DFA при динамічному дослідженні

\section{Лireparypa}

1 .Функциональное состояние организма беременных женщин при преэклампсиях различной степени тяжести / Сборник научных трудов "Актуальные вопросы интенсивной терапии." - Днепропетровск, 2011.

2.Оценка эффективности интенсивной терапии преэклампсий различной степени тяжести на основе анализа показателей вариабельности сердечного ритма / Сборник научных трудов "Актуальные вопросы интенсивной терапии". - Днепропетровск, 2011.

3. Флейшман А. Н. Медленные колебания гемодинамики. Теория, практическое применение в клинической медицине и профилактике / А. Н. Флейшман. - Новосибирск : Наука, 1999. - 266 с. відображає ефективність терапії, що проводиться, при преекслампсіях різного ступеня тяжкості.

Можливе використання нелінійних показників ВСР - DFA і CAT - як вхідні змінні для контролера дозатора лікувального препарату.

4. Heart rate variability: Standards of measurement, physiological interpretation and clinical use. Task Force of European Society of Cardiology and the North American Society of Pacing and Electrophysiology // Circulation. 1996. 93. 1043-1065.

5. Quantification of scaling exponents and crossover phenomena in nonstationary heartbeat time series / C.-K. Peng, Sh. Havlin, H. Stanley, A.Goldberger// Chaos. - 1995. - Vol. 5. - P. 82-87.

6. Levy M. Autonomic interactions in cardiac control: role of neuropeptides / M. Levy, M. Warner // Cardiac electrophysiology from cell to bedside. - Philadelphia, 1990. -P.305-312. 